\title{
日本の論文誌や科研費における研究組織の 協力体制や動向の可視化 \\ A research on visualization for collaboration research and its trend in Japanese journals or Grant-in-Aid
}

\author{
西澤 正己*、孫 媛、柿沼 澄男
}

Masaki NISHIZAWA, Yuan SUN and Sumio KAKINUMA

\author{
国立情報学研究所 情報社会相関研究系 \\ Information and Society Research Division, National Institute of Informatics \\ 干101-8430 千代田区一ツ橋 2-1-2 \\ Email: \{nisizawa, yuan, kakinuma \}@nii.ac.jp
}

学術研究においては、個人研究の夕ならず共同研究が数多くなされている。その中でも複数機関 にわたる共同研究は分野による違いが大きく現れる。我々は、日本の学術論文のデータベースであ る CJP データベースと科学研究費補助金成果概要データベースを用い、共著および研究分担者の 組織間の繋がりを可視化するソフトウェアを開発した。分野や年度、地域性等の状況を可視化し、主 に分析のための補助となる機能を多く盛り込んでいる。

Collaborating research is made abundantly in the academic research. A difference of aspect by the research field appears especially in collaboration work with several organizations. We develop software for visualization of collaborating research on CJP database and KAKEN database. This software is most useful for analyzing an aspect of fields, trends, and locality of academic research.

キーワード: 共同研究、研究動向、可視化

collaboration research, research trend, visualization

\section{1.はじめに}

我々はこれまでの研究において、特定の トピックに注目した研究分野間の関連分析 [1]や産学両セクタの共著論文からのわが 国の産学連携の実態・特徵・動向の分析 [2]をおこなってきた。

これらの分析を通じて、共同研究や共著 論文における研究態様が研究分野によっ て特徵が大きく違うことがわかってきてい
る。

これらの特徴をより明確に示すことを目標 として、研究組織の協力体制や動向を視覚 的に見つけるソフトウェアを開発した。今回 は開発期間が3か月と短く、また、今後の開 発のための基礎部分を重点的に開発した ため、まだ機能不足の面も数多く残ってい るが、第一期開発が終了したのでここで報 告する。

本システムは各機関ごとの研究課題数や 
論文数、またその共同研究や共著の関係 を日本地図上に示すシステムである。この システムで用いたデータは、研究課題とし て、国立情報学研究所が作成した、文部科 学省科学研究費補助金 (科研費)データベ ース(KAKEN)[3]、論文のデータとしては国 立情報学研究所が作成した「引用文献索 引データベース」(Citation database for Japanese Papers: CJP)[4]を用いた。どちらも、 研究者個人ではなく所属組織間の関係とし て調べるため、後で述べる組織名の名寄せ をした後にシステムにロードした。

\section{2. データベース}

\section{1 科学研究費補助金データベース}

国立情報学研究所では、「科学研究費 補助金採択課題・成果概要データベース （KAKEN）」[3]を作成し、公開している。こ のデータベースは 2 種類のデータベースか ら構成され、研究分担者の情報がある「科 学研究費補助金成果概要データベース」 の部分をこの研究に利用した。KAKEN デ 一タベースでは 1965 年から 2007 年のデー タが公開されているが、分析時点で成果概 要データベースの部分は 1985 年度から 2003 年度までが利用可能であった。本報 告のシステムには KAKEN データベースの 課題名、研究代表者および共同研究者の 所属組織名、研究種目、細目分野を使用し た。本システムにロードした研究種目および その件数を表 1 に示す。

\subsection{CJP データベース}

CJP は，国立情報学研究所が，その前身 である学術情報センター時代の 1995 年か ら作成している引用文献索引データベース
表1：科研データの研究種目とその件数

\begin{tabular}{|c|c|c|}
\hline 研究種目 & 研究種目番号 & 件数 \\
\hline 特別推進研究 & 10 & 1,001 \\
\hline 特別推進研究(COE) & 11 & 76 \\
\hline がん特別研究 & 21 & 1,943 \\
\hline 自然災害特別研究 & 22 & 211 \\
\hline 環境科学特別研究 & 23 & 317 \\
\hline エネルギー特別研究(エネルギー) & 24 & 233 \\
\hline エネルギー特別研究(核融合) & 25 & 368 \\
\hline 重点領域研究 & 30 & 23,023 \\
\hline 特定領域研究(A) & 31 & 8,795 \\
\hline 特定領域研究(B) & 32 & 2,035 \\
\hline 特定領域研究(C) & 33 & 1,666 \\
\hline 特定領域研究 & 34 & 14,671 \\
\hline 特定研究 & 40 & 1,968 \\
\hline 総合研究(A) & 50 & 6,183 \\
\hline 総合研究(B) & 60 & 836 \\
\hline 一般研究(A) & 70 & 6,056 \\
\hline 一般研究(B) & 80 & 26,706 \\
\hline 一般研究(C) & 90 & 72,785 \\
\hline 試験研究 & 120 & 3,831 \\
\hline 試験研究(A) & 121 & 199 \\
\hline 試験研究(B) & 122 & 7,633 \\
\hline 海外学術研究 & 160 & 9.359 \\
\hline 国際学術研究 & & \\
\hline 創成的基礎研究費 & 170 & 54 \\
\hline COE形成基礎研究費 & 180 & 151 \\
\hline 特別研究促進費 & 190 & 72 \\
\hline 奨励研究(A) & 210 & 57,137 \\
\hline 若手研究(A) & 250 & 1,659 \\
\hline 若手研究(B) & 260 & 35,433 \\
\hline 基盤研究(A) & 300 & 18,294 \\
\hline 基盤研究(B) & 310 & 69,234 \\
\hline 基盤研究(C) & 320 & 139,465 \\
\hline 基盤研究(S) & 330 & 949 \\
\hline 萌芽的研究 & 400 & 10,879 \\
\hline 萌芽研究 & 401 & 13,864 \\
\hline 地域連携推進研究 & 410 & 198 \\
\hline 学術創成研究費 & 420 & 215 \\
\hline 特別研究員奨励費 & 500 & 20,126 \\
\hline 合計 & & 557,625 \\
\hline
\end{tabular}

表 2: 分野別 CJP 収録雑誌数および論文数

\begin{tabular}{|c|c|c|c|c|}
\hline 分野 & サブ分野 & $\exists ー ト ゙$ & 椠誌数 & 論文数 \\
\hline \multirow{7}{*}{ 理学 } & 化学 & A1 & 49 & 32,954 \\
\hline & 科学教育 & A2 & 26 & 37,755 \\
\hline & 核科学 & A3 & 115 & 45,622 \\
\hline & 情報学 & A4 & 75 & 38,074 \\
\hline & 数学. 物理学. 天文学 & A5 & 24 & 13,662 \\
\hline & 生物科学 & A6 & 6 & 7,484 \\
\hline & 地質学·地理学·地球物理学 & A7 & 4 & 388 \\
\hline 理学 計 & & & 299 & 175,939 \\
\hline \multirow{7}{*}{ 工学 } & 応用化学 & B1 & 135 & 109,983 \\
\hline & 機械工学 & B2 & 93 & 87,546 \\
\hline & 金属工学 & B3 & 258 & 182,880 \\
\hline & 工学一般·応用物理学 & B4 & 72 & 69,127 \\
\hline & 資源開発工学 & B5 & 21 & 42,004 \\
\hline & 電気工学·電子工学 & B6 & 51 & 47,847 \\
\hline & 土木工学·建築学 & B7 & 34 & 28,627 \\
\hline \multirow[t]{4}{*}{ 工学 計 } & & & 664 & 568,014 \\
\hline & 家政学 & $\mathrm{C} 1$ & 42 & 22,536 \\
\hline & 水産学 & $\mathrm{C} 2$ & 42 & 29,552 \\
\hline & 畜産学·獸医学 & $\mathrm{C} 3$ & 17 & 9,154 \\
\hline \multirow{5}{*}{ 農学 } & 農学一般 & $\mathrm{C} 4$ & 19 & 10,058 \\
\hline & 農業経済学 & C5 & 49 & 12,201 \\
\hline & 農業工学 & c6 & 9 & 2,758 \\
\hline & 農芸化学·微生物学 & $\mathrm{c7}$ & 18 & 8,550 \\
\hline & 林学 & $\mathrm{C} 8$ & 10 & 5,095 \\
\hline \multirow[t]{3}{*}{ 農学 計 } & & & 206 & 99,904 \\
\hline & 歯科学 & D1 & 45 & 24,647 \\
\hline & 社会医学 & D2 & 60 & 36,504 \\
\hline \multirow{4}{*}{ 医学·歯学·薬学 } & 診療科学 & D3 & 288 & 231,993 \\
\hline & 生理学 & D4 & 130 & 82,517 \\
\hline & 病理学 & D5 & 82 & 46,815 \\
\hline & 薬科学 & D6 & 31 & 29,017 \\
\hline \multicolumn{3}{|c|}{$\frac{\text { 医学·歯学·薬学 計 }}{\text { 不明 }}$} & 636 & 451,493 \\
\hline \multirow{2}{*}{\multicolumn{3}{|c|}{$\begin{array}{l}\text { 不明 } \\
\text { 総計 }\end{array}$}} & & 40 \\
\hline & & & 1,805 & $1,295,390$ \\
\hline
\end{tabular}

で, 日本国内の自然科学分野の学術論文 誌・学協会誌論文が収録対象となっている。 CJPに収録された文献は，1995年から 2007 
年の一部までの 1,805 誌の 1,295,390 論文 に及ぶが, それらの文献には, 収録雑誌の 分類に従って, 分野分類が付与されている。 分野は,「理学(A1-7)」「工学(B1-7)」「農学 (C1-8)」「医学・歯学・薬学(D1-6)」の 4 つに 分けられ, それらがさらに細かいサブ分野 に分類されている。分野とサブ分野, およ びそれぞれに分類された雑誌と論文の件 数は, 表 2 に示す。なお、システム上では分 野はA1-D6 の表記中から選ぶことになって いる。

\section{3. ロードデータの処理}

\section{1 機関データの名寄せ}

CJP データベースにおいては、原データ では, 各論文について著者の所属機関名 が示されているが, その表記法が統一され ていない。だが, 本システムでは, 機関・組

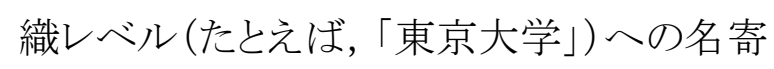
せが必要であるため, 著者所属機関名に ついて, 機械処理と目視調査点検を組み 合わせて, 分かち書きを行い, 必要な機関 名のみを抽出した。また，機関名の記述は， 基本的に原論文における表記をそのまま収 録しているので, 表記の「ゆれ」が多く含ま れている。たとえば,「東京大学」は,「東京 大」「東大」などと表記される場合があり，さ らに英語名による記載や誤字による「ゆれ」 も生じうる。したがって, 機関別集計におい ては,こうした機関名記述の統一が必要で あった。このため,まず機関名表記の「ゆ れ」の実態を調査し, 可能な事例について はその正規化プログラムを作成して処理し たほか, 目視による個別事例の点検, 調査 も併用して, 機関名の名寄せを行った。

今回使用した CJP データベースの全著
者数レコードは 4,400,686 件であつた。論文 の著者に対する所属機関データとして, 和 文所属(AFFN)と英文所属(AFFE)の二種類 のレコードがある。一般的に和文雑誌は AFFN のレコードに, 英文誌はAFFE のレコ ードに記述されているが, 原著に両方の記 述があるものは両方のレコードに所属の記 述がある。また, どちらにも所属情報が無い データもあるが、このようなデータは使用し ていない。

困1に名寄せ処理の流れを示す。AFFN のレコードと AFFE のレコードは異なる処理 をしているが, 処理 1 で文字表現の正規化 を行い, 処理 2 で所属機関名と所属部門 (上位, 下位)に分かち書きしている。ここで は, かなりの例外処理が必要で, 大学院大 学, 付属病院等, 細心の注意を払って分か ち書きをおこなっている。処理 3 においては, (株)や univ 等レコードの記述で判断できる 範囲で自動セクタ分類をおこなっている。 処理 4 においては、処理2で分かち書きし た日英表記の日本語表記を優先して、上 位レコードを組織名とする他、処理 3 で付

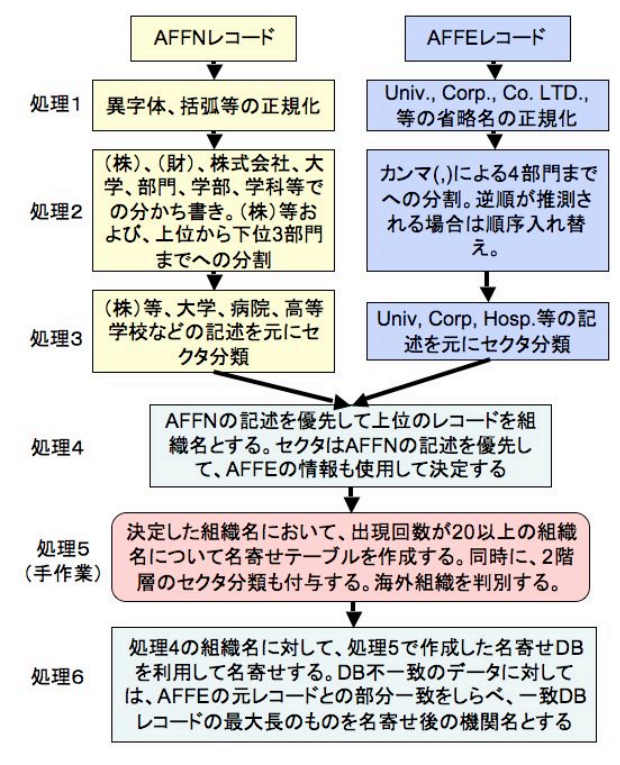

図1:名寄せ処理の流れ図 
与したセクタから日本語表記を優先してセ クタの自動付与をしている。処理 5 において は処理 4 の機関名で出現頻度が 20 以上の 機関名に対して名寄せテーブルを作成して いる。つまり、「東京大学」、「東大」、「東京 大」等の表記が各々 20 以上現れた場合、こ れらが名寄せテーブルに記述され、これら の標準表記を「東京大学」とすることにして いる。この処理はまだすべて終わっていな いが, 現時点で 18,214の表記ゆれに対し, 6,478 機関への名寄せテーブルを使用して いる。さらに,このテーブルに記述された機 関に関しては手作業で 2 階層のセクタ分類 をおこならと同時に, 海外機関の判別もおこ なっている。

処理 6 においては, 処理 5 で作成された 名寄せテーブルに対し, 処理 4 の機関名か ら名寄せをおこなっている。この名寄せ処 理によって全レコードの 88.5\%が名寄せ処 理されている。また, この処理では DB テー ブルのリストに無かった場合，さらに DB リス トと AFFE のオリジナルレコードとの部分一 致を取っている。この一致する DB レコード の最長レコードに対して名寄せ処理をおこ なっている。なお, DB レコードの中で 5 文 字以内のレコードに対しては, 大文字小文 字の区別をおこなって処理している。88.5\% の内 $1.7 \%$ がこの処理によって名寄せされて いる。

このような処理の後、CJPデータベースに 関しては、1,295,390 件の論文があり、この 中で複数機関が関与する論文は 401,811 件であった。

KAKEN データベースに関しては、CJPと 同様な処理を行っているが、英文レコード が無いため和文レコードに対する処理のみ をおこなっている。KAKEN データベースで
は 557,625 件の研究課題があり、この中で 複数機関が関与する課題数は 129,095 件 であった。

また、この処理においてはセクタ分類を 付与しているが、今回のシステムではまだ 利用していない。

\section{2 キーワードの作成}

システム中で検索に用いられるキーワ ードについてはCJPデータベースでは論文 タイトル、KAKEN データベースについては 研究課題名より形態素解析システム (ChaSen)を用いて単語に分解し、キーワー ドを抽出している。現在、この部分はソフト 開発会社が作成したものを使用しているが、 キーワードとしてふさわしくない語句（による、 のための・等)が含まれており、今後これま でに我々が開発してきたキーワード抽出手 法[1]に置き換える予定である。

\section{4. 可視化システムの概要}

\section{1 システム構成}

本システムは WEB ブラウザをクライアント とし、 linux システム上で稼働する WEB サー バーとで構成される。クライアントブラウザは FireFox 2.0、IE 6,7、Safari 3.1 サポートして いる。サーバのプログラミングは主にオブジ エク卜指向 perl で書かれており、データベー スソフトウェアとしては、MySQL[5]を使用し ている。

図2に処理の概要を示す。図中の処理の 内容を以下に示す。

（1）クライアントサイドからの要求をindex.cgi が受ける。 


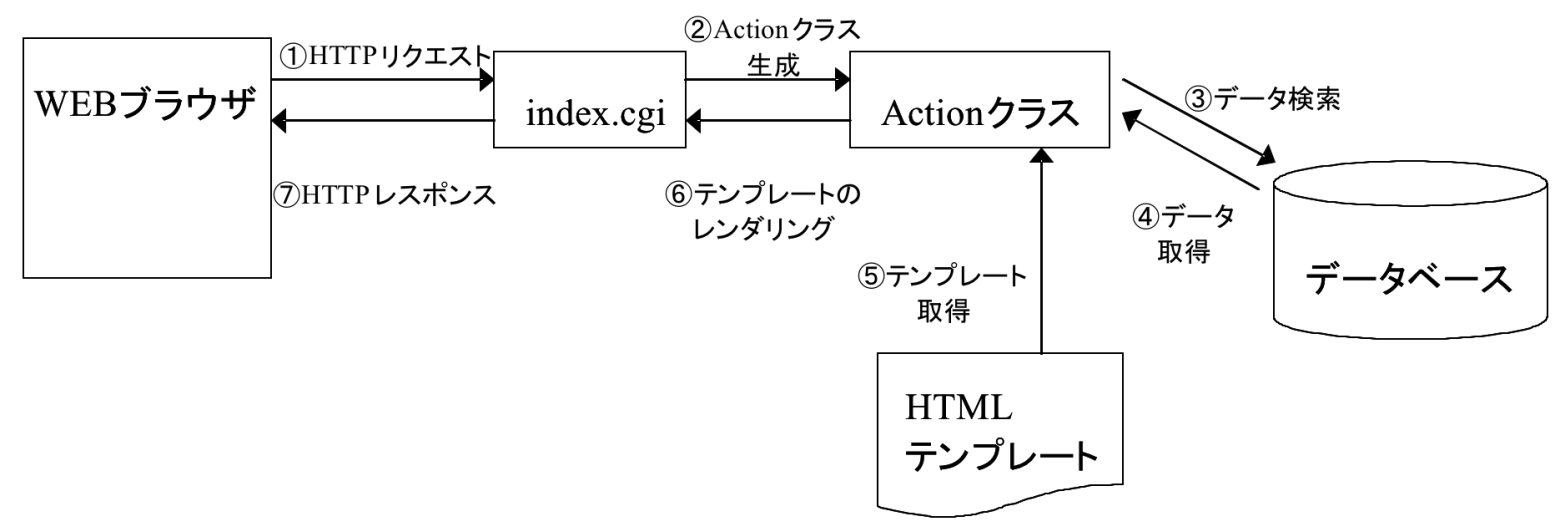

図 2：処理の概要

(2) index.cgi は、URL の action 引数に応じ て Action クラス名を決定し、Action クラス を生成する。

(3) Action クラスは必要に応じてデータベー スへのデータ検索、及びデータ取得を行 う。

（4）Action クラスはテンプレートの読み込み を行う。

(5) Action クラスは、(4)でデータベースより 取得したデータをテンプレートに渡してレ ンダリングを行う。

（5）レンダリングされた HTML は index.cgi を通して WEB ブラウザに返される。

\section{2 可視化の方法}

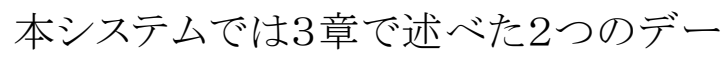
タベースから KAKEN では研究課題の研究 代表者および分担者の所属機関の組み合 わせ、CJP では論文の著者の所属機関の 組み合わせを元に、研究組織間の繋がりを 可視化する。

検索方法としては、2つのデータベース にはそれぞれ独自の研究分野分類がなさ れているため、KAKEN データベースでは 研究種目および細目分野、CJPデータベー
スでは雑誌の分野分類コードによって検索 できる。さらに、キーワード検索では各デー タベース個々の他、両方をまとめて検索で きるようにしている。年度に関しても指定し て検索できる。

本システムは一瀬らによる研究者コミュニ ティマイニングシステム[6]を元にして開発さ れた。システム内部では検索された研究課 題群および論文群に対する所属機関の組 み合わせをアイテムとし、各課題および論 文をトランザクションと考えたバスケット分析 [7]をおこなっている。データ数が多いため、 検索時間の短縮にはアプリオリアルゴリズム [7]を採用している。

本システムでは、研究機関の位置関係を 視覚的に見るため新たに地図上の研究機 関の位置に検索後の所属機関に対する課 題数または論文数を棒グラフで、その繫が りの強さをエッジの太さで示すようにしてい る。表示させるしきい值はサポート值によっ て与えることとする。

本システムの地図および研究機関の位 置情報取得には Google Map API[8]を用い ている。この API を用いて研究機関名から 地図上の位置を求めているため、内部的に 


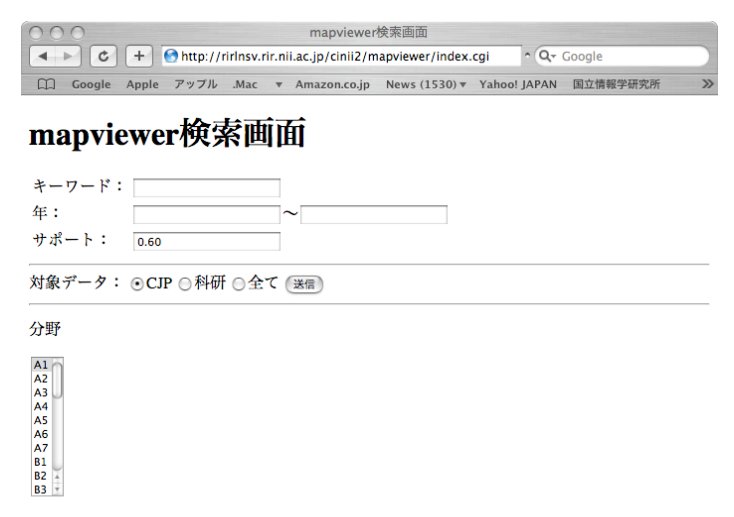

図 3-1：CJPデータベース検索画面

機関の位置情報を持つ必要がないが、動 作に再現性が無い部分があり、検索された 機関がすべて表示されない場合がある。こ れによる表示漏れを補うために同時に検索 結果を表でも見せているが、今後表示漏れ をなくすために内部で位置情報あるいは住 所の情報を持つように改良していくつもりに している。

\section{3 可視化システムの検索例}

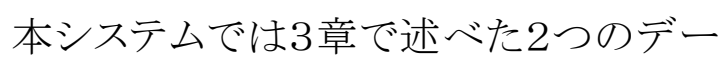
タベースからの検索をおこなうため、初期検 索画面では検索するデータベースの選択 ができる。困 3-1 には CJP データベースを 選択した例 (初期画面)、図 3-2 には KAKEN データベースを選択した例を示す。 両方のデータベースを選択したときには、 分野、研究種目、細目分野の選択画面は 出てこない。

KAKEN データベースでは、研究種目も 細目分野も数年ごとに変更がある。ロードさ れている 1985 年から 2003 年度の間のデー タでは、2002 年度に大きな変更が加えられ ている。このため、年度切替機能を入れ、こ



困 3-2：KAKEN データベース検索画面

の変化に対応している。また、細目分野名 の細かな変更については、新しい表記にま とめて表示している。研究種目によっては 細目分野が無い種目もある(特定領域研究 等)。これらの種目を選択した時には、細目 分野の選択は意味をなさなくしている。細 目分野のみを選択した時には、細目がある 研究種目のみが検索される。また、研究種 目、細目分野、CJP の分野においては複数 選択も可能である。

困 4-1 にはKAKENデータベースにおい て、教育学を選択した結果を示している。こ の画面では論文数と表示されているが、サ ポート值が 0.6 以上の研究機関の研究課題 数が棒グラフで表示されている。表ではす べての機関が表示されているが、マップ上 では Google Map API の関係で位置情報が 取れなかったものは表示できていない。こ れらは、表中にマップ可否で示されている。

図 4-2 では、図 4-1 の棒グラフで東京大 学を選択した時の画面である。サポート值 0.6 以上で東京大学と共同研究のある機関 が示されている。この中で東京大学は図 


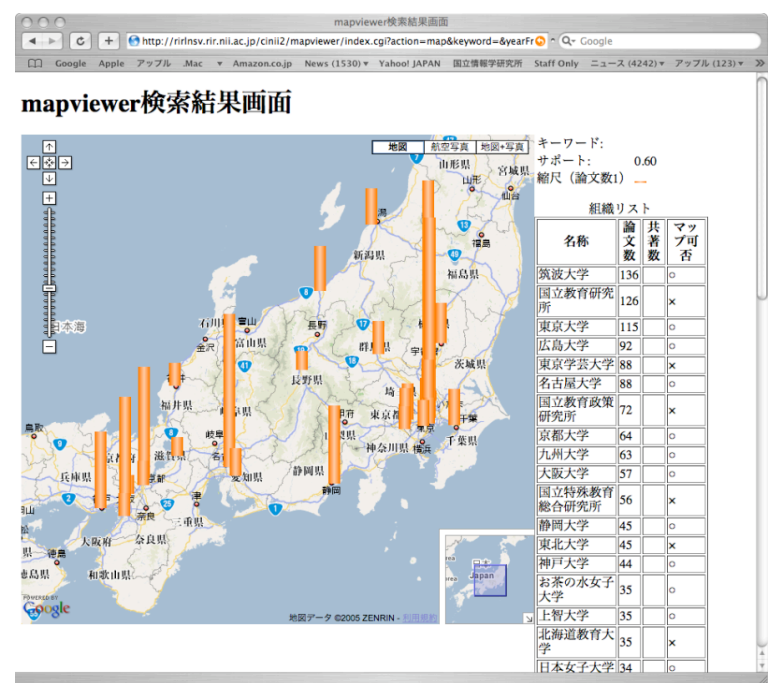

図 4-1：「教育学」細目分野検索画面

4-1 で示された課題数のすべてが表示され、 その他は東京大学との共同研究課題数が 棒グラフの下部に色を変えて表示されてい る。また、慗がりの強さは機関間のリンクの 太さで示している。画面の縮尺は Google Map と同様に可変できる。

図 5-1 は検索画面で CJP、KAKEN 両方 のデータベースを選択し、キーワード「情 報」で検索した結果の画面である。サポート 值は 0.6 である。表示は図4と同様で、眓中 で、東京大学を選択した時の連関を示した

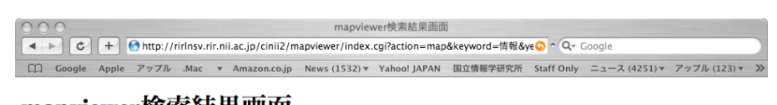

\section{mapviewer娭萦結果画面}

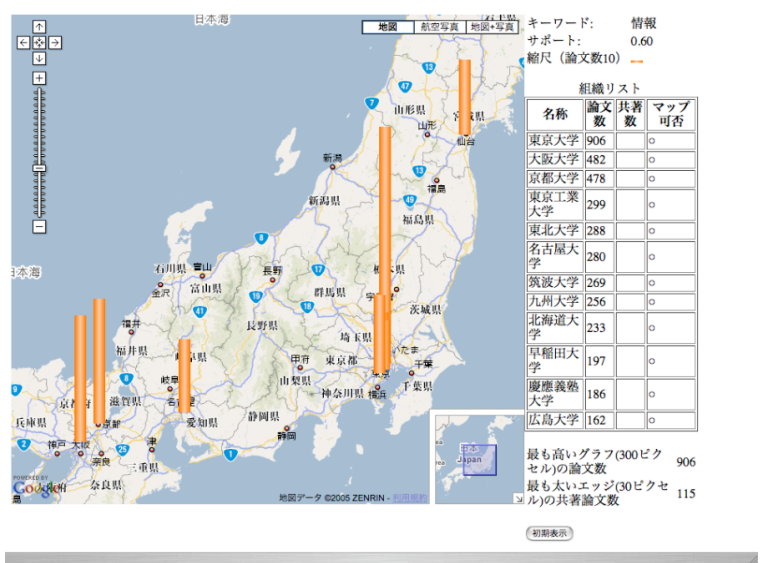

図 5-1：キーワード「情報」での検索画面

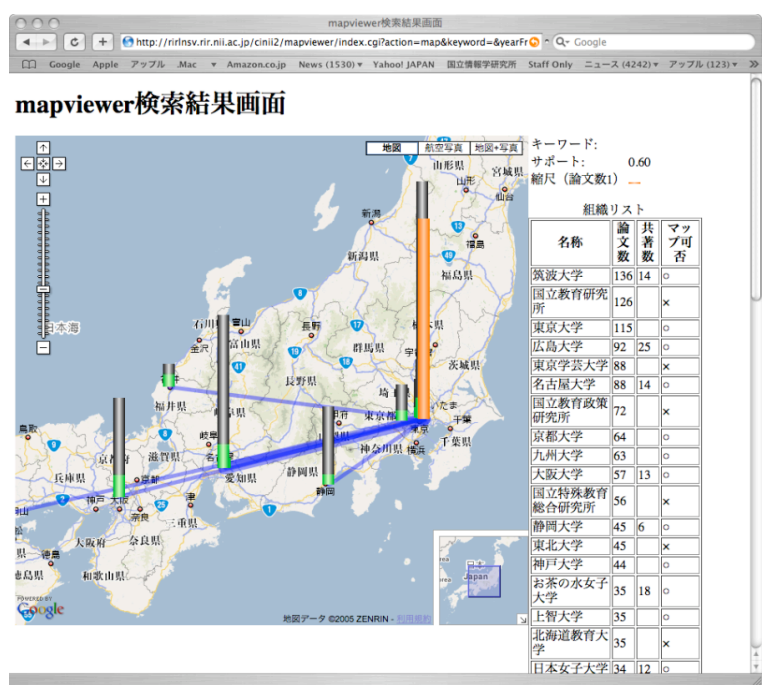

図 4-2：「教育学」の東京大学からみた連関

のが図 5-2 となる。ここでは、両方のデータ ベースを選択したが、キーワードを入力して 研究種目や細目分野、分野を選択しないこ とで、各データベースのキーワードのみの 検索もできる。

約3ヶ月と短い機関の開発であるので、 機能的に盛り込めなかった部分も多く、図 5-2 など小さな不具合も残っている。今回は 第一段階の開発と考えており、今後産官学 の連携具合などを可視化するシステムのべ 一スにしたいと考えている。

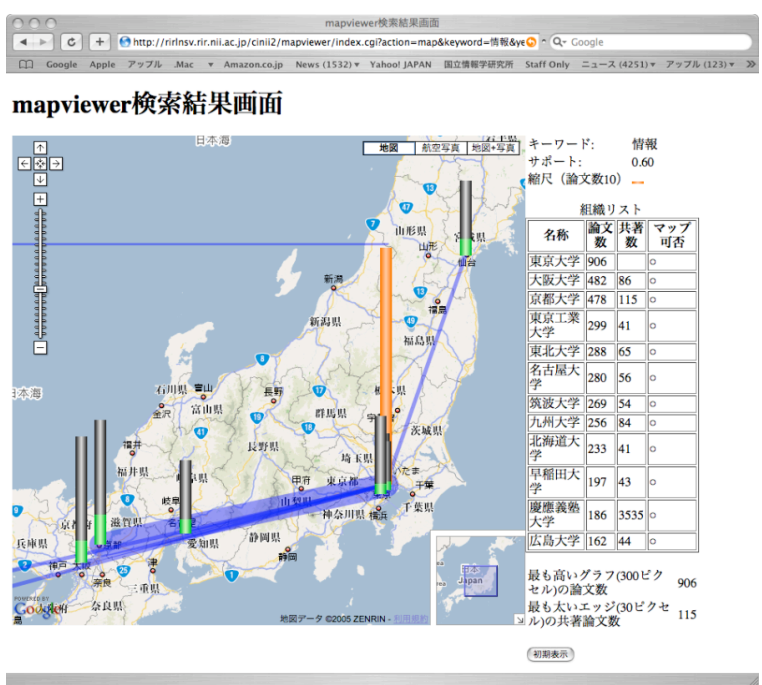

図 5-2：図 5-1 の東京大学からみた連関 


\section{まとめ}

我々は、日本の学術論文のデータベー スである CJP データベースと科学研究費補 助金成果概要データベースを用い、共著 者および研究分担者の組織間の繋がりを 可視化するソフトウェアを開発した。現時点 では、盛り込めなかった機能も多数あるが、 視覚的に研究機関の繋がりを見ることがで きるようになった。今後はさらに機能を追加 するとともに、科研費と成果論文の連関の 違いなどについても分析していきたいと思 っている。

\section{謝辞}

本研究は科学研究費補助金基盤研究 (B)、(19300083) および科学研究費補助金 基盤研究(A)、(17200010)の助成を受けた ものである。開発においては一瀬龍太郎氏、 武田英明氏に助言をいただき、システムの 開発ベースとして先行事例を利用させてい
ただいた。ここに厚く感謝する。

\section{参考文献}

［1］西澤 正己、孫 媛，「キーワード分析によ る科研費におけるゲノムおよびナノテクノロジー 関連研究の動向調査」, 情報知識学会誌, Vol.17, No.2, pp.117-122, 2007

[2] 孫媛, 西澤正己, 柿沼澄男, 根岸正光「日 本の学会誌論文の共著関係からみた産学連 携」2007 年度新領域融合プロジェクトによる研 究会「大規模データ・リンケージ，データマイニ ングと統計手法」統計数理研究所, pp.13-21, (2008)

[3] 2005 年 4 月から「科学研究費補助金採択課 題速報データベース(KAKENK)」と「科学研究 費補助金成果概要データベース (KAKEN)」を 統合して科学研究費補助金データベース (KAKEN) としてサービスされている。: http://seika.nii.ac.jp/

[4] CiNii データベースサービスの一部として公 開されている。:http://ci.nii.ac.jp/

[5] MySQL, http://dev.mysql.com/

[6] 一瀬 龍太郎, 研究者コミュニティマイニン グ シ ス ム http://ri-www.nii.ac.jp/ComMining2/descripti on/index.html

[7] 福田 剛志 他, 「データマインング」, 共 立出版 (2001)

[8] Google Map API: http://code.google.com/intl/ja/apis/maps/ 